\title{
Controlling Stormwater from Logging Roads: The Case for Permitting
}

\author{
Alex Hardee*
}

In Decker v. Northwest Environmental Defense Center, an environmental nonprofit sought to bring stormwater pollution from logging roads under the ambit of the Clean Water Act's National Pollutant Discharge Elimination System, which was originally designed for point source discharges. The Supreme Court ruled that these discharges did not require National Pollutant Discharge Elimination System permits, and thus that Oregon was not in violation of the Clean Water Act for allowing unpermitted stormwater discharges in its state forests. In this paper, I argue that permitting stormwater discharges from logging roads is necessary to overcome collective action problems at the state level, and that it can be achieved despite the Court's ruling in Decker. I propose utilizing general permits, which would avoid the administrative burdens of the individual permit process. Such a system can take advantage of the benefits of current best management practices while improving upon their weaknesses.

Introduction

I. Federal Water Pollution Controls: The Clean Water Act....................295

A. History of the CWA....................................................................295

B. Point and Nonpoint Sources .......................................................2295

C. The 1987 Stormwater Amendments .............................................2297

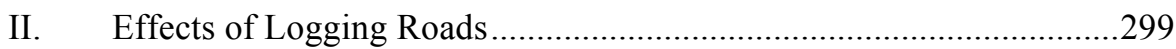

III. Northwest Environmental Defense Center's Lawsuit ............................301

A. Northwest Environmental Defense Center v. Brown (2011)...........301

B. Decker v. Northwest Environmental Defense Center (2013) ...........302

IV. State BMPs Are Inadequate to Mitigate Stormwater Effects.................303

A. Theoretical Background ...........................................................304

1. Collective Action Problems .....................................................304



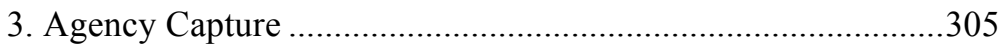

4. The Oregon Forest Practices Act ........................................307

Copyright (C) 2014 Regents of the University of California.

J.D. Candidate, University of California, Berkeley School of Law (Boalt Hall), 2015. The author wishes to thank Professor Holly Doremus, Elisabeth Long, I-Wei Wang, and Ryan Hart for their insightful comments and dedicated guidance. 
5. Toward Finding Solutions

V. Federal Permitting

A. Federal Permitting Comports with the CWA and the 1987 Amendments

B. Success With General Permitting for Other Systems ......................313

C. The Forest Road Stormwater Permitting Process ...........................316

D. Advantages of General Permitting Applied to Logging.................319

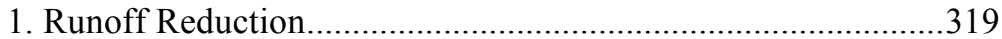

2. Compliance with Water Quality Standards ............................320

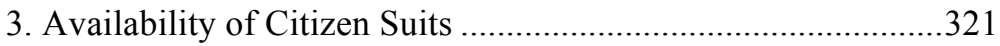

E. Potential Problems With General Permitting Applied to Logging ...322

\section{INTRODUCTION}

Rain is an integral part of the water cycle, bringing water vapor in the atmosphere to earth, where it sustains nearly all forms of life. For salmon that begin their lives in Oregon rivers, however, a coming rain can be a death sentence. Sediment pollution from stormwater runoff smothers their eggs, reduces dissolved oxygen levels, interferes with feeding, and buries insects that provide food. ${ }^{1}$ Despite more than forty years of water pollution regulation under the federal Clean Water Act (CWA), many of the nation's waters remain polluted. Stormwater runoff, in spite of federal and state efforts to control it, continues to be an intractable problem. The Environmental Protection Agency (EPA) estimates that stormwater runoff has polluted 850,000 acres of lakes, reservoirs, and ponds, and 50,000 miles of rivers and streams in the United States. $^{2}$

In Decker v. Northwest Environmental Defense Center, an environmental nonprofit sought to bring stormwater pollution from logging roads under the ambit of the CWA's National Pollutant Discharge Elimination System (NPDES), which was originally designed for point source discharges. The Supreme Court ruled that these discharges did not require NPDES permits, and thus that Oregon was not in violation of the CWA for allowing unpermitted stormwater discharges in its state forests. ${ }^{3}$

I argue that this outcome is inconsistent with the goals of the CWA, and that managing forest stormwater discharges through permitting would be a beneficial policy choice. Stormwater runoff is possibly the single greatest impediment to the CWA's objective: "to restore and maintain the chemical,

1. See Nw. Envtl. Def. Ctr. v. Brown (Brown III), 640 F.3d 1063, 1067 (9th Cir. 2011).

2. See Annie Snider, EPA Report Outlines Development Impacts, Options for Reducing Damage, E\&E NEWS PM (June 17, 2013), http://www.eenews.net/eenewspm/stories/1059982988.

3. Decker v. Nw. Envtl. Def. Ctr., 133 S. Ct. 1326 (2013). 
physical, and biological integrity of the Nation's waters."4 Notwithstanding the Court's holding in Decker, EPA has the authority to initiate a permitting system for logging road stormwater discharges. I propose utilizing general permits, which would avoid the administrative burdens of the individual permit process. Such a system can marshal the benefits of current best management practices (BMPs) while improving upon their weaknesses. I argue that, as with point source pollution, federal regulation of stormwater sources can be instrumental in overcoming collective action problems at the state level. EPA has already demonstrated the effectiveness of general permits for municipal separate sewer systems (MS4s) and pesticides; these sources are analogous to logging roads in important ways. I begin this discussion with the history and goals of the CWA itself.

\section{Federal Water Pollution Controls: The Clean Water Act}

\section{A. History of the CWA}

In 1969, the Cuyahoga River in Cleveland, coated with a slick of volatile industrial waste, caught fire. ${ }^{5}$ This dramatic event, and others like it, highlighted a water pollution crisis in America. Congress swiftly responded with the Federal Water Pollution Control Act (FWPCA) Amendments of $1972,{ }^{6}$ renamed the Clean Water Act in $1977 .{ }^{7}$ President Nixon vetoed the CWA out of economic concerns, citing its "extreme and needless overspending." 8 Although Congress overrode Nixon's veto with bipartisan support, his message continues to reverberate for practitioners, activists, and policy makers who contemplate the Act's future challenges. It is an open question whether the nation is willing to pay for long-term improvements in its waters.

\section{B. Point and Nonpoint Sources}

The heart of the CWA is section 301, which broadly prohibits discharges of pollutants into the nation's waters, except as in compliance with specific provisions of the CWA. ${ }^{9}$ This broad statutory prohibition shifted the burden of proof from the government, which no longer had to prove injury to prohibit

4. $\quad$ CWA $\S 101(a), 33$ U.S.C. $\S 1251$ (2012).

5. Philip Shabecoff, A Fierce Green Fire: The American Environmental Movement 103 (2d ed. 2003); Brown III, 640 F.3d at 1070.

6. CWA § 101.

7. This Note will use "CWA," but quotations containing "FWPCA" refer to the same statute.

8. Message From the President of the United States Returning Without Approval the Bill (S. 2770) Entitled "The Federal Water Pollution Control Act Amendments of 1972," quoted in Maria V. Maurrasse, Oklahoma v. EPA: Does the Clean Water Act Provide an Effective Remedy to Downstream States or Is There Still Room Left for Federal Common Law?, 45 U. MiAmI L. Rev. 1137, 1148-49 n.85 (1991).

9. CWA $\S 301$. 
pollution, to the discharger, which had to justify a given discharge. ${ }^{10}$ Section 402(a) created NPDES, which required permits for pollution discharges and defined pollution abatement requirements for permits based on "best available technology." "NPDES applies only to "point sources," which the CWA defines as: "any discernible, confined, and discrete conveyance, including ... any pipe, ditch, channel, tunnel, [or] conduit ...."12

Nonpoint source pollution, by contrast, is not defined in the CWA, but it is widely understood to arise from many dispersed activities over large areas, and not traceable to any single discrete source. ${ }^{13}$ Nonpoint source pollution is difficult to regulate through individual permits. ${ }^{14}$ The most common example of nonpoint source pollution is residue that automobiles leave on roadways: small amounts of rubber from tires, copper and dust from brake linings, and drips of oil-all of which wash off roads and into waterways when it rains. ${ }^{15}$

Since its inception, the CWA has prioritized reducing point source pollution, which it regulates strictly. In contrast, it deals less directly with nonpoint sources. Many features of the CWA, such as effluent standards, permits, and enforcement, do not apply to nonpoint sources. ${ }^{16}$ Although the CWA contains several programs intended to address nonpoint source pollution, it leaves the ultimate responsibility to the states. ${ }^{17}$ If a state's program is deficient or nonexistent, none of the CWA's nonpoint programs contain express authority for EPA to prepare a nonpoint source control program. ${ }^{18}$ Because the CWA treats nonpoint source pollution as "something of an afterthought," this type of pollution is now the largest single obstacle to improving water quality in the United States. ${ }^{19}$

Logging road stormwater discharges have similarly received less federal attention than traditional point sources. For instance, EPA's first regulatory

10. Robert W. Adler et Al., The Clean WAter ACt 20 Years LAter 8 (1993).

11. CWA $\S 301(\mathrm{~b})(2)(\mathrm{A}) ;$ id. $\S 402(\mathrm{a})(1)$.

12. CWA $\S 502(14)$.

13. See League of Wilderness Defenders/Blue Mountains Biodiversity Project v. Forsgren, 309 F.3d 1181, 1184 (9th Cir. 2002).

14. See id.

15. See id.

16. WiLliam H. RODGERS JR., ENVIRONMENTAL LAW 127 (1986).

17. Edward B. Witte \& Natalia Minkel-Dumit, Nonpoint Source Pollution Control, in THE CLEAN WATER ACT HANDBOOK 192-94 (Mark A. Ryan ed., 3d ed. 2011). CWA nonpoint programs include sections 208, 303(e), and 319. Section 208 is primarily a planning provision, requiring each state's governor to identify areas in the state with substantial water quality problems, and to create an "areawide waste management plan" for each. Id. at 195. Section 303(e) requires each state to implement a continuous planning process for all of the state's navigable waters, incorporating their section 208 areawide management plans into an overall continuing planning process. Id. Congress added section 319 in 1987 to address growing awareness of the problem of nonpoint source pollution-and the ineffectiveness of existing control measures. $I d$. at 196 . However, section 319 is still predominantly a planning provision, requiring states to develop nonpoint source pollution assessment reports by 1998, and then adopt nonpoint source management programs. Id.

18. Robert W. Adler, Integrated Approaches to Water Pollution: Lessons from the Clean Air Act, 23 HARV. ENVTL. L. REV. 203, 228 (1999).

19. William L. Andreen, Water Quality Today: Has the Clean Water Act Been a Success?, 55 Ala. L. Rev. 537, 593 (2004). 
guidance was to categorically exempt them. It made this choice despite recognizing that if channeled through a pipe, ditch, or other conveyance, the discharges technically meet the definition of "point source." ${ }^{20}$ EPA claims it did so to conserve its enforcement resources for "more significant" sources of pollution. ${ }^{21}$ The Natural Resources Defense Council successfully challenged this exemption as inconsistent with the CWA in Natural Resources Defense Council v. Train. ${ }^{22}$ Pending appeal, EPA began to revise its rules, albeit adhering to the position that "it would be administratively difficult if not impossible, given Federal and State resources to issue individual permits to all such point sources." 23 It released what became its official guidance on loggingbased sources included in the NPDES system: the "Silvicultural Rule." ${ }^{24}$ This Rule states that the term "silvicultural point source" means any discernible, confined, and discrete conveyance related to "rock crushing, gravel washing, $\log$ sorting, or log storage facilities" that are operated in connection with silvicultural activities. ${ }^{25}$ Meanwhile, the D.C. Circuit affirmed the district court's disapproval of EPA's broad 1973 stormwater exemptions in Natural Resources Defense Council v. Costle. ${ }^{26}$ It did not review EPA's 1976 Silvicultural Rule. The current version of the Rule is mostly unaltered from the 1976 version. ${ }^{27}$

\section{C. $\quad$ The 1987 Stormwater Amendments}

By the mid-1980s, Congress had become dissatisfied with the lack of progress in controlling stormwater runoff. It passed amendments to the CWA that gave control of some stormwater sources to NPDES. Until 1987, EPA treated stormwater as a diffuse source of nonpoint source pollution-the justification was that runoff cannot be controlled using the strict end-of-pipe effluent limitations that regulate traditional industrial and municipal discharges. ${ }^{28}$ However, as EPA itself recognized, stormwater is often discharged through discrete channels or conveyances, or separate storm sewers, and thus legally meets the definition of a "point source."29

20. 40 C.F.R. $\S 125.4$ (2013).

21. Brief for the United States Supporting Petitioners at 3, Decker v. Nw. Envtl. Def. Ctr., $133 \mathrm{~S}$. Ct. 1326 (2013) (No. 11-338), 2012 WL 3864278, at*3.

22. See Natural Res. Def. Council v. Train, 396 F. Supp. 1393 (D.D.C. 1975).

23. National Pollution Discharge Elimination System, 40 Fed. Reg. 56,932 (proposed Dec. 5, 1975) (to be codified at 40 C.F.R. pts. 124, 125).

24. 41 Fed. Reg. 6281, 6282 (proposed Feb. 12, 1976) (to be codified at 40 C.F.R. pts. 124, 125).

25. 40 C.F.R. $\S 124.85$. Under the Silvicultural Rule, all silvicultural discharges that do not fit into these four categories are considered nonpoint source pollution.

26. Natural Res. Def. Council v. Costle, 568 F.2d 1369 (D.C. Cir. 1977).

27. Brown III, 640 F.3d at 1077 ("The current text of the ... Silvicultural Rule is different in only minor respects from the version promulgated in 1976.")

28. Randy Hill \& David Allnutt, "Wet Weather" Regulations, in THE CLEAN WATER ACT HANDBOOK 163 (Mark A. Ryan ed., 2d ed. 2003).

29. Id. at 164; see also National Pollution Discharge Elimination System, 40 Fed. Reg. 56,932 (proposed Dec. 5, 1975) (to be codified at 40 C.F.R. pts. 124, 125) (indicating "a need to consider the 
Because stormwater is often a point source (at least technically), and because EPA's approach was failing to create progress, Congress decided to add several categories of stormwater discharge to the NPDES permitting system. ${ }^{30}$ Senator Durenberger explained that despite the CWA's clear directive to regulate stormwater, EPA had failed to require most stormwater point sources to apply for NPDES permits. ${ }^{31}$ Congress recognized that the delay stemmed from the great number of stormwater sources meeting the definition of a point source, and thus the lengthy process of creating the necessary permits. ${ }^{32}$ Its solution, CWA section 402(p), was a tiered system that regulated the most significant sources first. "Phase I," the first tier, covers five categories of stormwater discharges, including those "associated with industrial activity." 33 Congress required a permit for Phase I discharges by $1990 .{ }^{34}$ All remaining stormwater discharges were regulated as "Phase II," through which EPA was to study discharges not covered by Phase I and issue regulations based on its studies. ${ }^{35}$

EPA promulgated Phase I regulations in 1990, meeting Congress's deadline. ${ }^{36}$ For discharges in the "associated with industrial activity" category, EPA issued what is now known as the Industrial Stormwater Rule. Stormwater discharge "associated with industrial activity" means discharge from a stormwater conveyance that is directly related to "manufacturing, processing or raw materials storage areas at an industrial plant." 37 It expressly exempts from

desirability of attempting to apply the permit system to all point sources conceivably covered by the broad definitional framework established by the [FWPCA]").

30. See CWA $\S 402(p), 33$ U.S.C. $\S 1342(p)$ (2012).

31. 132 CONG. REC. 32,380, 32,400 (Oct. 16, 1986).

32. See, e.g., 131 CONG. REC. 19,846, 19,850 (Jul. 22, 1985) (statement of Rep. Rowland) ("What we are talking about is potentially thousands of permits for churches, schools, residential property, runoff that poses no environmental threat ....").

33. CWA $\S 402(\mathrm{p})(2)(B)$. The other four categories are:

(A) A discharge with respect to which a permit has been issued under this section before the date of the enactment of this subsection; ... (C) A discharge from a municipal separate storm sewer system serving a population of 250,000 or more; (D) A discharge from a municipal separate storm sewer system serving a population of 100,000 or more but less than 250,000 ; (E) A discharge for which the Administrator or the State, as the case may be, determines that the stormwater discharge contributes to a violation of a water quality standard or is a significant contributor of pollutants to waters of the United States. Id.

34. CWA $\S 402(\mathrm{p})(4)(\mathrm{A})$.

35. CWA $\S 402(p)(5)-(6)$. One example of EPA's Phase II regulation is the Small MS4 program, which applies to regulated small MS4s, and prescribes certain minimum control measures, such as illicit discharge detection and elimination, construction site runoff control, and permitting and reporting requirements. See EPA, StORMWATER PHASE II FinAl RUle (2012), available at http://www.epa.gov/ npdes/pubs/fact2-1.pdf; Revisions to Stormwater Regulations to Clarify That an NPDES Permit Is Not Required for Stormwater Discharges from Logging Roads, 77 Fed. Reg. 72,970 (December 7, 2012) (to be codified at 40 C.F.R. pt. 122).

36. National Pollutant Discharge Elimination System Permit Application Regulations for Storm Water Discharges, 55 Fed. Reg. 47,990 (Nov. 16, 1990) (to be codified at 40 C.F.R. pts. 122-124); 40 C.F.R. $\S 122.26(2013)$.

37. 40 C.F.R. $\S 122.26(b)(14)$. 
this definition any activity that is already defined as a nonpoint source in the Silvicultural Rule. ${ }^{38}$

\section{EFFECTS OF LOGGING ROADS}

Forests in the United States fulfill varied and conflicting roles, including recreation, wildlife habitat, and lumber production. ${ }^{39}$ Logging continues to be one of the main uses of public forest land in the United States. ${ }^{40}$ One of its most significant negative impacts is water pollution. ${ }^{41}$ Deforestation, forest road development, timber harvesting activities, mechanical site preparation, pesticide application, and prescribed burning all threaten water sources, including wetlands, streams, lakes, and groundwater. ${ }^{42}$ Of all silvicultural activities, the construction and maintenance of logging roads poses the greatest potential harm to water quality and wetlands. ${ }^{43}$ Road activities generate numerous water pollutants including pesticides, fuels, lubricants, and sediment, which is composed of gravel, rocks, and wood chips. ${ }^{44}$

Forest roads are constructed with a system of ditches, culverts, and channels, which collect stormwater runoff and convey it into streams and rivers. ${ }^{45}$ When it rains, runoff carries the numerous pollutants into waterways, where they have numerous adverse consequences on the ecosystem, and are particularly harmful for anadromous fish. ${ }^{46}$ Salmon need cold, clear water,

38. The Silvicultural Rule is codified in 40 C.F.R. $\S 122.27$.

39. See Terry L. Anderson \& Donald R. Leal, Free Market Environmentalism: Hindsight and Foresight, 8 CORNELL J.L. \& PUB. POL'Y 111, 120 (1998) (arguing that forest management must balance a number of competing and conflicting interests).

40. See U.S. DEP'T OF AGRIC., U.S. FOREST FACTS \& HistORICAL TRENDS 6 (2001) available at: http://www.fia.fs.fed.us/library/briefings-summaries-overviews/docs/ForestFactsMetric.pdf.

41. See Samuel P. Hays, The New Environmental Forest, 59 U. CoLO. L. REV. 517, 526 (1988) (noting that "timber cutting expose[s] soils to erosion and create[s] undesirable sedimentation in irrigation and urban water supplies").

42. See Dan Binkley \& Thomas C. Brown, Forest Practices as Nonpoint Sources of Pollution in North America, 29 J. AM. RESOURCES ASS'N 729, 729 (1993), available at http://www.fs.fed.us/ rm/value/docs/forest_practices_nonpoint_pollution.pdf ("Forest management practices, such as road construction, harvesting, and regeneration may substantially alter the quality of water draining from forested watersheds.").

43. U.S. Forest SERV., Water Quality and Wetlands, in PROTECTING WATER QUALITY AND Wetlands in Forest MANAgEMENT: Best MANAGEMENT PRACTICES IN MinNesota 4 (1995), available at http://www.nrs.fs.fed.us/fmg/nfmg/docs/mn/WaterQ.pdf. The U.S. Forest Service attributes this impact to the "concentration of activity, the extent of area affected, the amount of disturbed and exposed soil, and the relative permanence of a forest road." Id.

44. Binkley \& Brown, supra note 42, at 729. See also ThOMAs C. BROWN \& DAN BinKLEY, U.S. FOREST SERV. GENERAL TECHNICAL REPORT RM-248, EFFECTS OF MANAGEMENT ON WATER QUALITY IN NORTH AMERICAN FORESTS 1, 14 (1994), available at http://www.fs.fed.us/rm/value/docs/ management_effects_forest_water_quality.pdf.

45. $I d$.

46. Brown III, 640 F.3d at 1067. Anadromous fish, including salmon and steelhead, spend the first portion of their life cycle in freshwater streams in forested areas, then migrate downstream to estuarine habitats before growing to maturity in the ocean. Id. They then return to the stream in which they were born to spawn. Id. Sediment pollution also destroys aquatic habitat and increases the cost of treating drinking water. EPA, WHAT IS SEDIMENT POLLUTION? (undated), available at http://cfpub.epa.gov/npstbx/files/ksmo_sediment.pdf. 
clean gravel beds, and pools where their young can find food and shelter. ${ }^{47}$ Sediment from logging roads adversely affects each of these habitat features. ${ }^{48}$ The National Oceanic and Atmospheric Administration has noted that in the Pacific Northwest, logging road networks are the most significant source of sediment to anadromous fish habitats - greater than all other land management activities combined. ${ }^{49}$ EPA has documented that hundreds of thousands of river miles in numerous states are impaired by sediment pollution. ${ }^{50}$

This pollution has greatly harmed anadromous fish populations. A comprehensive scientific stock assessment by the American Fisheries Society found that 214 distinct stocks of anadromous fish in California, Idaho, Oregon, and Washington were at risk of extinction, with 100 stocks already extinct. ${ }^{51}$ Since that report's release in 1991, twenty-eight populations of salmonids have been listed as endangered or threatened under the Endangered Species Act. ${ }^{52}$

Despite these problems, states and EPA have for decades agreed that the best way to address logging road stormwater pollution is through state BMPs, rather than through the NPDES system. ${ }^{53}$ Although the CWA and its amendments initiated the formal development of forestry BMPs, federal oversight of state programs has been far lower than for NPDES-permitted sources. ${ }^{54}$ EPA's delegation of authority to the states on this issue dates to 1973, when EPA promulgated the broad exemptions for agricultural and silvicultural activities that were struck down in Train and Costle, discussed above. ${ }^{55}$ EPA's position in 1975 was that "most rainfall runoff is more properly regulated under section 208 of the FWPCA, whether or not the rainfall happens

47. Brown III, 640 F.3d at 1067.

48. Id. Sediment smothers eggs, reduces oxygen levels, interferes with feeding, and buries insects that provide food. $I d$.

49. Nat'l Marine Fisheries Serv., FaCtors for Decline: A Supplement to the Notice of DETERMINATION FOR WeST COAST STEELHEAd UNDER THE ENDANGERED SPECIES ACT 19 (1996),

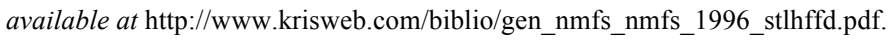

50. National Summary of Impaired Waters and TMDL Information, EPA, http://iaspub.epa.gov/ waters10/attains_nation_cy.control?p_report_type=T\#imp_water_by_state (last updated Apr. 18, 2014). For instance, just four Western states have more than 100,000 miles of impaired rivers and streams. California has more than 29,000; Oregon has 31,000; Idaho has 34,000; and Montana has 17,000. Id.

51. W. Nehlsen et al., Pacific Salmon at the Crossroads: Stocks at Risk from California, Oregon, Idaho, and Washington, 16 FISHERIES 4, 4-21 (1991).

52. Endangered Species Act Status of West Coast Salmon and Steelhead, NAT'L OCEANIC \& ATMOSPHERIC ADMIN., http://www.westcoast.fisheries.noaa.gov/protected_species/salmon_steelhead/ salmon_and_steelhead_listings/salmon_and_steelhead_listings.html (last visited Apr. 17, 2014).

53. See Brief for Arkansas as Amicus Curiae Supporting Petitioner at 16, Decker v. Nw. Envtl. Def. Ctr., 133 S. Ct. 1326 (2013) (No. 11-338), 2011 WL 4941018, at*16.

54. W. Michael Aust \& Charles R. Blinn, Forestry Best Management Practices for Timber Harvesting and Site Preparation in the Eastern United States: An Overview of Water Quality and Productivity Research During the Past 20 Years (1982-2002), 4 WATER, AIR \& SOIL POLluTION: Focus 5, 6 (2004).

55. 40 C.F.R. $\S 125.4(\mathrm{j})$ (2013); see Form and Guidelines Regarding Agriculture and Silvicultural Activities, 38 Fed. Reg. 18,000, 18,000-04 (July 5, 1973) (to be codified at 40 C.F.R. pts. 124, 125); see also Natural Res. Def. Council v. Train, 396 F. Supp. 1393, 1395 (D.D.C. 1975); Natural Res. Def. Council v. Costle, 568 F.2d 1369, 1369 (D.C. Cir. 1977). 
to collect before flowing into navigable waters."56 Even after Congress passed the 1987 stormwater amendments, which were clearly designed to compel action on regulating stormwater, EPA's position continued to be that requiring NPDES permits for stormwater was an "unwieldy" regulatory tool. 57 A majority of states believe that a fully permitted approach for managing forest stormwater would overburden state agencies, which are already struggling to meet the other demands of the NPDES system. ${ }^{58}$

\section{NORTHWEST ENVIRONMENTAL DEFENSE CENTER's LAWSUIT}

\section{A. Northwest Environmental Defense Center v. Brown (2011)}

While the National Environmental Defense Center's (NEDC) lawsuit had national implications, it focused on just two logging roads in the Tillamook State Forest near Portland, Oregon: Trask River Road and Sam Downs Road. ${ }^{59}$ These roads run parallel to the South Fork Trask River and the Little South Fork of the Kilchis River, ${ }^{60}$ and are primarily used to haul logs out of the forest. ${ }^{61}$ A series of ditches and channels conveys stormwater from the roads into adjacent streams and rivers. Sediment from the roads caused by passing $\log$ trucks runs into the rivers, where it impairs water quality and kills salmon and trout. ${ }^{62}$ In light of what it considered continuing unpermitted discharges into the rivers, NEDC brought suit against the Oregon State Forester and the Oregon Board of Forestry and several timber companies in 2006. It sought to enjoin the discharges under the CWA's citizen suit provision, CWA section 505(a), which provides that any citizen can commence a suit against "any person" alleged to be in violation of the CWA. The District Court for the District of Oregon concluded that the discharges were exempted from NPDES permitting by the Silvicultural Rule, and it dismissed NEDC's suit for failure to state a claim. ${ }^{63}$ NEDC appealed.

The Ninth Circuit reversed. ${ }^{64}$ On the merits, it first addressed the Silvicultural Rule, finding it subject to two possible readings. ${ }^{65}$ Under EPA's

56. National Pollutant Discharge Elimination System, 40 Fed. Reg. 56,932, 56,935 (proposed Dec. 5, 1975) (to be codified at 40 C.F.R. pts. 124, 125).

57. Brief for the United States Supporting Petitioners, supra note 21, at 13.

58. Brief for the State of Arkansas Supporting Petitioners, supra note 53, at 2.

59. Brown III, 640 F.3d at 1067.

60. Id.

61. Id.

62. Id.

63. Nw. Envtl. Def. Ctr. v. Brown (Brown I), 476 F. Supp. 2d 1188 (D. Or. 2007).

64. Nw. Envtl. Def. Ctr. v. Brown (Brown II), 617 F.3d 1176 (9th Cir. 2010). The court denied the appellees' petition for rehearing and rehearing en banc in May 2011, filing a new opinion that differed from the 2010 opinion only in that it contained an additional discussion of subject matter jurisdiction based on an amicus brief from the United States. See Brown III, 640 F.3d at 1066. The United States, reflecting the view of EPA, had argued that the suit should have been brought under CWA section 509(b), 33 U.S.C. § 1369(b) (2012), which provides for the review of actions of the EPA Administrator. Based on the Ninth Circuit's 2010 opinion, the United States conceded that the Ninth Circuit had subject matter jurisdiction under section 505(a). Id. at 1068. 
preferred interpretation, the Ninth Circuit found the current Silvicultural Rule to be similar to the original version struck down in Train and Costle, which categorically exempted all discharges from silvicultural activities. ${ }^{66}$ EPA's interpretation of the current Rule did not go that far, but it still categorically exempted all discharges that cause natural runoff. ${ }^{67}$ Since this exemption applied regardless of how discharges were collected and channeled, the Ninth Circuit found it invalid because it conflicted with the CWA's definition of a point source, which focuses on channeling. ${ }^{68}$ The court upheld the Rule through an alternative reading. ${ }^{69}$ Under this reading, the Rule exempts natural runoff from silvicultural activities as long as it remains "natural," but ceases to exempt runoff channeled in some systematic way through a "discernible, confined, and discrete conveyance." 70 Under either reading of the Silvicultural Rule, the Ninth Circuit found that the defendants were liable for discharging channeled stormwater into the two rivers without NPDES permits.

In the alternative, the defendants claimed that even if the Silvicultural Rule did not exempt the discharges under section 502(14), they are nonetheless exempt from permitting because of the 1987 CWA stormwater amendments. The Ninth Circuit ruled that logging roads fall under EPA's Phase I regulations because they are "associated with industrial activity" according to the language of the Industrial Stormwater Rule. Because the court found the logging roads in question to be part of Phase I, it concluded that they required NPDES permits, despite EPA's wish to carve out exemptions. ${ }^{71}$ It supported this conclusion by appealing to industry categorization. Industries in the Phase I "associated with industrial activity" category are defined by Standard Industrial Classification. ${ }^{72}$ The Industrial Stormwater Rule applies to Standard Industrial Classification 24, which contains "logging," among other industries. ${ }^{73}$ The Ninth Circuit used this evidence to conclude that logging is undisputedly an "industrial activity," and therefore subject to Phase I permitting because of its inclusion in the Industrial Stormwater Rule. ${ }^{74}$

\section{B. Decker v. Northwest Environmental Defense Center (2013)}

The Supreme Court granted certiorari. ${ }^{75}$ It first determined whether there was still a live controversy, since EPA amended the Industrial Stormwater Rule

65. Id. at 1080 .

66. Id. at 1078; see also Natural Res. Def. Council v. Train, 396 F. Supp. 1393 (D.D.C. 1975); Natural Res. Def. Council v. Costle, 568 F.2d 1369 (D.C. Cir. 1977).

67. Brown III, 640 F.3d at 1078.

68. See CWA $\S 502(14)$.

69. Brown III, $640 \mathrm{~F} .3 \mathrm{~d}$ at 1080.

70. Id.; CWA $\S 502(14)$.

71. Id. at 1085 .

72. Brown III, 640 F.3d at 1083 .

73. 40 C.F.R. $\S 122.26($ b)(14)(ii) (2013).

74. Brown III, 640 F.3d at 1083.

75. Decker v. Nw. Envtl. Def. Ctr., 133 S. Ct. 1326 (2013). The case name changed because during litigation the Oregon State Forester changed from Marvin Brown to Doug Decker. 
during litigation to expressly exclude "logging." 76 The Court sided with NEDC, ruling that there was a continuing controversy over whether the defendants were liable for past discharges under the earlier version of the Industrial Stormwater Rule. ${ }^{77}$

The Court next reached the merits. ${ }^{78}$ It found that according to the preamendment Industrial Stormwater Rule, EPA's view that logging roads are not industrial sources was entitled to deference. ${ }^{79}$ Despite NEDC's argument that the preamendment version of the Rule included the Standard Industrial Classification for "logging," the Court decided that logging is not one of the "categories of industries" contemplated in the Industrial Stormwater Rule. It sided with EPA's view that logging is not reasonably related to manufacturing, processing, or raw materials storage areas at an industrial plant, which are the three main categories that the Rule includes. ${ }^{80}$

The Court justified its decision with two reasons. The first is that under Auer deference, when an agency interprets its own regulation, courts will defer to it "unless that interpretation is plainly erroneous or inconsistent with the regulation." 81 The Court's second justification was the "background of state regulation" on stormwater runoff from logging roads. ${ }^{82}$ It cited several of Oregon's logging BMPs, such as a rule requiring logging companies to construct roads using surfacing that minimizes sedimentation. ${ }^{83}$

\section{State BMPs ARE InAdequate to Mitigate Stormwater EFfects}

Although the states argued to the Court that NPDES permits for forest stormwater would be duplicative and cost-prohibitive, I seek to show that they would be neither. Furthermore, I believe that NPDES permitting is a necessary regulatory reform because existing state BMPs are not doing enough to protect rivers and streams from stormwater runoff. In this section, I identify deficiencies in the Oregon Forest Practices Act (FPA) and show that they are exactly what relevant economic theory predicts.

76. Decker, 133 S. Ct. at 1335. EPA restricted covered discharges to the four categories of rock crushing, gravel washing, log sorting, or log storage facilities. Id. The amendment's purpose was to shrink the logging-related activities covered in the Phase I "industrial" category to those four activities already listed in the Silvicultural Rule-unambiguously removing "logging" as a category. Id. Petitioners, with the support of EPA, claimed that this rule change rendered the case moot. Id.

77. Id.

78. As with the Ninth Circuit, the Court accepted the premise that according to the 1987 amendments, defendants need only secure NPDES permits for stormwater discharges "associated with industrial activity."

79. Decker, 133 S. Ct. at 1336-37.

80. Id.; see 40 C.F.R. § 122.26(b)(14) (2013).

81. Auer v. Robbins, 519 U.S. 452, 561 (1997); see Decker,133 S. Ct. at 1337. Justice Scalia dissented on this conclusion. He noted that Auer deference is misguided because it encourages agencies to write vague regulations so that they can retain flexibility. He concluded that the fairest reading of the CWA is that the discharges in question were point sources. Id. at 1341 (Scalia, J., concurring part and dissenting in part).

82. Id. at 1338 (majority opinion).

83. Id.; Ore. Admin. Rule 629-625-0700(2) (2012). 


\section{A. Theoretical Background}

\section{Collective Action Problems}

Economist Mancur Olson authored the first major study of collective action, challenging the conventional wisdom of his day. ${ }^{84}$ Olson disputed the notion that groups of individuals with common interests usually attempt to further those common interests. ${ }^{85}$ Other theorists had assumed that collective action followed logically from the premise of rational, self-interested behavior. ${ }^{86}$ Olson observed that organizations appear to work primarily for the common interests of their members, but that the members still retain their purely individual interests, which will often impede the group's objectives. ${ }^{87}$

Collective action problems are common in natural resource contexts. Suppose that a state provides an environmental public good-cclean water"and that people can act to either exploit it (yielding private benefit $x_{1}$ ) or use it sustainably (yielding lower private benefit $x_{2}$ ). Clean water is non-excludable, meaning those who seek a sustainable use will be unable to prevent its exploitation by those who seek higher short-term profits. Furthermore, their efforts at preservation will accrue to the entire group, benefitting the exploiters just as much as it benefits the sustainable users. The sustainable users' rational response would be to cease their efforts to preserve, and to take up the exploitative use. ${ }^{88}$ This basic mechanism is what makes preservation of public goods so challenging.

\section{Negative Externalities}

Even in the presence of effective institutions and accurate measurement, pollution may be produced at a level higher than is socially optimal. Anytime the marginal social cost of an action is greater than the marginal private cost, a rational actor will produce more than is socially optimal. This situation is called a negative externality because the costs of such an action are borne by society at large: they are externalized from the producer's vantage point. ${ }^{89}$ Allen Kneese and Blair Bower note that although a stream's capacity to assimilate

84. Mancur Olson, The Logic of Collective Action 6-11 (2d ed. 1971).

85. Id.

86. Id. at 7 .

87. $I d$.

88. See Garrett Hardin, The Tragedy of the Commons, 162 SCI. 1243, 1244 (1968). Hardin uses the example of a group of herdsmen each contemplating whether to add an additional animal to his herd.

[T] he rational herdsman concludes that the only sensible course for him to pursue is to add another animal to his herd. And another; and another.... But this is the very conclusion reached by each and every rational herdsman sharing a commons. Therein is the tragedy. Each man is locked into a system that compels him to increase his herd without limit-in a world that is limited. . . Freedom in a commons brings ruin to all.

Id.

89. See Allen V. Neese \& Blair T. Bower, Managing Water Quality: Economics, POLICY, INSTITUTIONS 77 (1968). 
pollution may be large, at some point significant costs will become apparent. For instance, fish will die and municipalities will have to treat their water rather than relying on clean natural sources. However, because many waste dischargers do not bear these costs individually, they will not weigh them in their decision making. ${ }^{90}$ Kneese and Bower concluded that society must find ways to optimally control these external effects, balancing the costs of waste discharge with the cost of controlling it. ${ }^{91}$ The classic solution, as proposed by economist A.C. Pigou, is to level against the producer a per-unit tax that approximates the social cost of the pollution..$^{92}$ However, while some Western European countries have used effluent charges to abate water pollution, the United States has not taken this approach. ${ }^{93}$

In Decker, the Pacific Coast Federation of Fishermen's Associations expressly noted the existence of negative externalities in an amicus brief on behalf of respondents. ${ }^{94}$ It claimed that logging road sediment directly damages fisheries, as well as water treatment facilities, and concluded that regulation under the CWA was essential to prevent timber interests from shifting the costs of their activities to downstream economic interests. ${ }^{95}$

\section{Agency Capture}

A third problem exacerbates the first two by making potential regulatory solutions harder to execute. Regulation emerged in the United States to combat widely occurring negative externalities and failures to manage common resources. ${ }^{96}$ Congress enacted numerous statutes in the 1970 s to deal with environmental problems, similar to its action in the 1930s to provide relief from the Great Depression and more effectively regulate financial transactions. ${ }^{97}$ An unfortunate side effect of this regulation is that industries, which interact with their regulating agencies, have been able to seek regulations that benefit them rather than the general public. Professor Oliver Houck has noted that for many problems, such as dairy pollution in Wisconsin, hog pollution in North Carolina, and logging pollution in Oregon and Maine, industries have

90. Id. at 78 .

91. Id.

92. See Robert H. Stavins, Res. for the Future Discussion Paper 01-58, Experience With MARKET-BASED ENVIRONMENTAL POLICy InSTRUMENTS 7 (2001), available at http://www.rff.org/ documents/rff-dp-01-58.pdf.

93. Id. at 8. For instance, NPDES largely functions through technology requirements rather than market pricing.

94. See Brief for Pacific Coast Federation of Fishermen's Associations as Amicus Curiae Supporting Respondent at 5-6, Decker v. Nw. Envtl. Def. Ctr., 133 S. Ct. 1326 (2013) (No. 11-338), 2012 WL 5353859, at *5-6.

95. Id. at $15-17$.

96. See KNEESE \& BOWER, supra note 89 , at $98-142$ (discussing effluent charges and water quality standards, which can both reduce water pollution).

97. See Marver H. Bernstein, Regulating Business by IndePendent Commission 53 (1955). 
maintained a political lock on state legislatures and in some cases on Congress. $^{98}$

Olson noticed that relatively small groups are often able to mobilize support for concentrated benefits at the expense of a larger total cost spread among the public. Equally problematic, small groups are often able to prevent regulatory actions that impose concentrated costs on them, yet are beneficial in the aggregate. Olson called this problem the "exploitation of the great by the small." 99 Professor Marver Bernstein augmented this theory by documenting how a regulatory agency gradually becomes "captured" by the industry it regulates. ${ }^{100}$ Bernstein theorized that following the passage of regulatory legislation, the agency is endowed with an "aggressive, crusading spirit," demonstrating daring and inventiveness in resolving regulatory problems. ${ }^{101}$ Gradually, public support for regulation fades away, agency passivity grows, and there is an increasing desire to avoid conflicts and enjoy good relationships with regulated groups. Finally, the agency has no "creative force" left to mobilize against the regulated groups. ${ }^{102}$

Professor Joel Mintz recently applied Bernstein's theory to EPA. The EPA's authorizing statutes tend to be lengthier, more detailed, and more directive of specific agency actions than the legislation that authorized the independent commissions that Bernstein studied in the $1950 \mathrm{~s} .{ }^{103}$ In response to Bernstein's criticisms, Congress created more detailed regulatory statutes that were more specifically directive toward regulatory agencies than in the past. ${ }^{104}$ The statutes also injected more public participation into agency decision making. Also, in response to the capture model, Congress began passing more "coercive" statutes, which remove an agency's discretion to regulate, but permit the agency to choose the appropriate method of regulation. ${ }^{105}$

Mintz found that EPA has managed to avoid Bernstein's worst predictions, although its enforcement work has bordered on captivity at several points, especially during the early 1980s. ${ }^{106}$ EPA fortunately had the support of the President when it was under attack from Congress, and vice versa. ${ }^{107}$ Consistent with Bernstein's theory, EPA operates in an antagonistic political environment. ${ }^{108}$ Regulated industries and trade groups have fought EPA since its inception in the 1970s, culminating in a bitter political struggle in 1995 over

98. Oliver Houck, The Clean Water Act TMDL Program: Law, Policy, AND IMPLEMENTATION 4 (2002).

99. OLSON, supra note 84 , at 29-30.

100. BERNSTEIN, supra note 97 , at $74-83$.

101. Id.

102. Id.

103. JoEl Mintz, ENFORCEMENT AT EPA: High StAKES AND HARD CHOICES 220 (2012).

104. Id.

105. Id. at 210 . Note that the 1987 stormwater amendments are precisely the type of "coercive" regulation that Bernstein contemplated, removing the agency's ability to delay through hard targets.

106. Id. at 217 .

107. Id. at 219 .

108. Id. at 215 . 
whether to slash its budget. ${ }^{109}$ Although EPA has survived numerous challenges, the antagonism it has faced from industry and Congress has undoubtedly made it careful about creating new regulatory programs.

Oregon is likely to suffer from some degree of regulatory capture. Although EPA has largely been able to avoid capture, it is plausible that smaller state environmental agencies will be captured by a regionally important industry because the factors that Mintz found have protected EPA are all absent at the state level. Furthermore, when an industry has a significant impact on the state's economy, it has the potential to influence the democratic process and influence regulations in its favor at the expense of the public - the "exploitation of the great by the small" that Olson noted. ${ }^{110}$

\section{The Oregon Forest Practices Act}

In the absence of NPDES permitting for forest roads, Oregon's rivers and streams are dependent on BMPs, which stem from the applicable land management law. Oregon's FPA, which governs logging activities on state and private land, displays each of the problems predicted in the literature. I believe that the FPA does not do enough to protect waterways from the harmful effects of logging, and that NPDES permitting would provide a way forward. In Decker, the Court cited several provisions of the FPA as proof that regulation under the CWA may be "duplicative or counterproductive."111 I will show instead that since the state-level rules are deficient, NPDES permitting would serve only to remedy them, and would neither duplicate nor frustrate state-level efforts to control stormwater.

As a threshold matter, some of Oregon's characteristics suggest high logging industry influence in policy making. The Oregon forestry sector accounts for 6.8 percent of the state's gross domestic product, employing 76,000 people and providing $\$ 5.2$ billion in wage and benefit income. ${ }^{112}$ The total economic output supported directly and indirectly by Oregon's forest sector is about $\$ 22$ billion, or 11 percent of Oregon's gross domestic product. ${ }^{113}$ In some counties, notably Lake, Clatsop, and Klamath, the forest

109. Id. at 215-18.

110. For instance, in West Virginia, where coal mining has steadily composed 6 to 7 percent of the state's gross domestic product, the coal industry has maintained a close relationship with regulators and has spent millions of dollars to support candidates who favor coal-friendly policies. See Diana Kaneva, Let's Face Facts, These Mountains Won't Grow Back: Reducing the Environmental Impact of Mountaintop Removal Coal Mining in Appalachia, 35 WM. \& MARY ENVT'L L. \& POL'Y REV. 931, 953 (2011).

111. Id. at 15. Consider that the mere existence of a statute or regulation directed at a problem does not indicate that it is solving the problem. For instance, most federal environmental statutes replaced less effective federal or state precursors. The CWA itself replaced preexisting yet largely ineffective state water quality standards. See Brown III, 640 F.3d at 1070.

112. OR. FOREST RES. INST., 2012 FOREST REPORT 4 (2012), available at http://oregonforests.org/ sites/default/files/publications/pdf/Poised_to_Rebound_online.pdf.

113. OR. DEP'T OF FORESTRY, FOREST FACTS (2009), available at http://www.oregon.gov/ odf/pubs/docs/forest_facts/ffforestryfactsfigures.pdf. 
sector accounts for as much as 25 to 30 percent of gross domestic product. ${ }^{114}$ Moreover, the operation of the FPA suggests that the Oregon Department of Forestry predominantly serves the timber industry. ${ }^{115}$ Although the FPA claims to balance demand for jobs, revenue, clean water, recreation, and wildlife habitat, ${ }^{116}$ it is deficient in numerous areas.

The FPA has important implications for how forest land is managed. Much of the detail of the FPA is contained in its implementing administrative rules. ${ }^{117}$ Although Justice Kennedy's majority opinion in Decker did not refer to the FPA by name, it cited FPA rules for the proposition that state-level regulations are doing enough, and that federal regulation is unnecessary. ${ }^{118}$ The Oregon logging industry is also a strong supporter of the FPA. ${ }^{119}$ One reason is that it makes regulations on state and private lands uniform across the state. In contrast to local governments, which have attempted to use land use plans and zoning rules to protect natural resources such as riparian vegetation, ${ }^{120}$ the timber industry preferred planting, growing, and harvesting of trees to be regulated solely by the FPA. ${ }^{121}$ With the support of the timber industry, the Oregon Legislature in 1979 passed H.B. 3008, which provides for the supremacy of the FPA and prohibits local governments from regulating forest operations governed by the FPA or its implementing rules. ${ }^{122}$ Another reason is that the FPA's regulations are substantially more permissive than comparable federal or state rules, which reduces costs to the logging industry.

Although the FPA's provisions are facially protective, they are also vague, such that deference to them could result in a broad range of acceptable practices. Although the FPA mentions controlling runoff from forest roads in a number of cases, the implementing rules are not specific about what the FPA requires. For instance, Oregon Administrative Rule 629-625-0600 deals with road maintenance. Subpart (4) provides that "[o]perators shall provide effective road surface drainage, such as water barring, surface crowning, constructing sediment barriers, or outsloping prior to the rainy and runoff seasons."123 A related rule requires that "[o]perators shall construct dips, grade reversals or other effective water diversions in skid trails and fire trails as necessary to minimize soil displacement and to ensure runoff water is filtered before

114. OR. FOREST RES. INST., supra note 112, at 4.

115. Id.

116. Id. at 9 .

117. Edward J. Sullivan \& Alexia Solomou, "Preserving Forest Lands for Forest Uses"-Land Use Policies for Oregon Forest Lands, 26 J. ENVTL. L. \& LiTIG. 179, 231 (2011).

118. See Decker v. Nw. Envtl. Def. Ctr., 133 S. Ct. 1326, 1338 (2013). Cited measures included Oregon Administrative Rule 629-625-0330(4) (2012), mandating filtration of stormwater runoff before it enters rivers and streams, and Rule 629-625-0700(2), requiring logging companies to construct roads using surfacing that minimizes the sediment in runoff. $I d$.

119. Sullivan \& Solomou, supra note 117 , at 230-31.

120. Id. at 231 .

121. Id.

122. Id. at 233-34.

123. OR. ADMIN. R. 629-625-0600. 
entering waters of the state." 124 I believe that the provisions "as necessary" and "effective" are too vague to provide substantive protection to components of the ecosystem, such as salmon, which bear the external costs of the logging industry's practices.

Although Oregon provides a "guidance manual" for each of these rules, containing applicable BMPs, they too suffer from ambiguity and vagueness. The BMPs specify what qualifies as an "unsatisfactory condition," 125 and how to identify decreases in water quality. ${ }^{126}$ However, it is unlikely that these general guidelines are enforced to a great extent. ${ }^{127}$ The BMPs' lack of specificity is evident in the compliance section of the road surface drainage rule, Rule 629-625-0600(4), which simply states that "an operator is in compliance with this rule when all active and inactive road surfaces are appropriately maintained before the rainy and runoff seasons." 128 This virtually tautological statement does not help to explain which specific practices will appropriately mitigate stormwater pollution.

Comparable rules for logging roads in other states contain noticeably higher protection for waterways. For instance, the rules implementing California's Z'Berg-Nejedly Forest Practices Act contain quantitative limits on sloping, fill, and sidecast to prevent erosion. ${ }^{129}$ Where a road section greater than 100 feet crosses slopes greater than 65 percent, placement of fill is prohibited and placement of sidecast shall be minimized to the degree feasible. ${ }^{130}$ Similarly, the rules specify quantitative limits on fill for a given slope and road length. ${ }^{131}$ An analysis of the California FPA determined that use

124. OR. ADMIN. R. 629-630-0300(2).

125. OR. DeP'T OF Forestry, OREgOn Forest Practice Rule Guidance, Division 625, RoAD CONSTRUCTION AND MAINTENANCE 77 (2009), available at http://www.oregon.gov/odf/privateforests/ docs/guidance/oardiv625.pdf ("When there is potential for erosion and sediment delivery to waterways because road surfaces have not been outsloped, crowned, water barred, or protected by other means.").

126. Or. Dep't of Forestry, Oregon Forest Practice Rule Guidance, Division 630, HARVESTING (2009) available at http://www.oregon.gov/odf/privateforests/docs/guidance/oardiv630.pdf ("When a visible increase in turbidity from the water conditions 100 feet upstream of the entry site continues for two or more hours in a twenty-four hour period.").

127. Matthew Preusch, Budget Cuts Could Mean the End of Oregon's Forest Protection Rules, OREGONIAN (Dec. 6, 2009), http://www.oregonlive.com/environment/index.ssf/2009/12/post_9.html (noting that many existing rules will become voluntary "guidelines," which will reduce the possibility of enforcement).

128. OR. DEP'T OF FORESTRY, supra note 125 , at 77.

129. CAL. CODE REGS. tit. 14, chs. 4, 4.5 \& 10 (2013), available at http://calfire.ca.gov/ resource_mgt/downloads/2013_FP_Rulebook_with_Tech_RuleNo1.pdf. Logging road construction is specifically addressed in sections $923.2,943.2$, and $963.2(\mathrm{~b})$.

130. Id. $\S \S 923.2,943.2,963.2(\mathrm{~b})$.

131. Id. at $\S \S 923.2,943.2,963.2(\mathrm{c})$. On slopes greater than 50 percent, where the length of a road section is greater than 100 feet, the road is more than 15 feet wide, and fill is more than 4 feet in vertical height, a road is to be constructed on an excavated bench, and the fill must be compacted. Id. Other relevant rules include section 963.2(i) ("Where there is evidence that soil and other debris is likely to significantly reduce culvert capacity below design flow, oversize culverts, trash racks, or similar devices shall be installed in a manner that minimizes culvert blockage.”) and sections 923.4, 943.4, 963.4(f), addressing road maintenance ("Drainage structures, if not adequate to carry water from the fifty-year 
of erosion hazard ratings, with site-specific elements of weather, slope, and soil determinations, has greatly reduced erosion problems, and that cross drain specifications and spacings determined by erosion hazard ratings has helped to keep soils in place. ${ }^{132}$

Similarly, Washington's Forest Practices Act and its implementing rules contain discrete provisions to protect waterways from erosion. One such rule is that erodible soils disturbed during road construction and located near streams must be seeded with noninvasive plant species. ${ }^{133}$ Maintenance rules are also specific: groundwater that has been captured by ditchline must be diverted onto stable portions of the forest floor, road surfaces must be maintained to minimize sediment entry into waterways, and before the first winter rainy season, drainage structures must be cleared and the road surface must be crowned, outsloped, water barred, or otherwise prepared to prevent accelerated erosion. ${ }^{134}$ Oregon's FPA lags behind both Washington and federal forest practices rules on protection of fish-bearing streams. For instance, Washington's riparian buffers for fish-bearing streams range from thirty to fifty feet from the stream's varying edges. ${ }^{135}$ On federal land managed under the Northwest Forest Plan, virtually all logging is prohibited for 300 to 340 feet from the edge of the stream channel. ${ }^{136}$ By contrast, Oregon's no-cut buffers are typically between ten and twenty feet. ${ }^{137}$

The FPA, which governs timber practices on state and private land, is also significantly less protective than federal standards that govern National Forest System and Bureau of Land Management land. For one, public participation on federal lands is enhanced through the National Environmental Policy Act, which requires federal agencies to inform the public of potentially significant decisions. ${ }^{138}$ Federal logging regulations themselves are stronger than the FPA. For instance, federal standards prohibit clearcutting of old-growth wildlife reserves and require the retention of six to eight live green trees per acre in Northern Oregon and sixteen to twenty-five trees per acre in Southern

flood level, shall be removed . . . by the first day of the winter period, before the flow of water exceeds their capacity if operations are conducted during the winter period, or by the end of timber operations whichever occurs first.").

132. Donald P. Gasser, Lessons from California's Forest Practices Act, in FAO FOREST CODES OF Practice: Contributing to Environmentally Sound Forest Operations, FAO Forestry PAPER No. 133 (Dennis P. Dykstra \& Rudolf Heinrich eds., 1996), available at http://www.fao.org/docrep/w3646e/w3646e0g.htm.

133. WASH. ADMIN. CODE $\S$ 222-24-030(4) (2013), available at http://www.dnr.wa.gov/ Publications/fp_rules_ch222-24wac.pdf.

134. Id. § 222-24-052(1).

135. Forest Practices on Private Lands in Oregon, PAC. RIVERS COUNCIL, http://pacificrivers.org/ conservation-priorities/land-management/forest-practices/forest-practices-on-private-lands-in-oregon (last visited Apr. 17, 2014).

136. Id.

137. See OR. ADMIN. R. 629-640-000(7) (2014) ("In order to ensure compliance with state water quality standards, these rules include requirements to retain all trees within 20 feet and understory vegetation within 10 feet of the high water level of specified channels to provide shade.").

138. See Nat'l Envtl. Policy Act $\S 102(c)(i v), 42$ U.S.C. $§ 4332(2)$ (2012). 
Oregon. ${ }^{139}$ If regeneration harvest is practiced, rotation age must be at least sixty years. ${ }^{140}$ The FPA, by contrast, allows clearcuts on up to 120 -acre parcels and places no limits on rotation age. ${ }^{141}$ Steve Pedery, conservation director of the environmental nonprofit Oregon Wild, has noted that environmental groups have sought to change logging rules in Oregon to including more environmentally sensitive timber harvests in state-owned forests, but that it has been difficult to change the FPA in the legislature. ${ }^{142}$ Republicans and rural Democrats have defended the current law. ${ }^{143}$ This evidence only serves to reinforce my prediction that state-level collective action problems necessitate a federal solution to the forest stormwater problem. The next Part explains the benefits of federal permitting to this issue and proposes a workable solution for how NPDES forest stormwater permits would actually work.

\section{Toward Finding Solutions}

One possible solution to undervalued and under-protected natural systems is to incorporate ecosystem services into our property rights regime. Professor Joseph Sax argues that existing property and regulatory systems have failed to recognize and protect the important services that land performs in its unaltered state. ${ }^{144}$ The modern "transformative economy" considers land inert, valuable only for the wealth of its resources, such as timber. Even as people began to acknowledge the toll of development on natural resources, the pollution laws they created did not demand that land adjacent to a river be treated as part of its riparian zone, or that it be left to perform natural functions of the ecosystem. ${ }^{145}$ Rivers and their adjoining lands are still treated for the most part as separate tracts. To the extent that this disjunction has created ecological loss, we have sought to replace it with technological solutions rather than to repair the ecosystem. For instance, when clearing of upstream lands has created

139. Letter from John K. Raby, Field Manager, Butte Falls Res. Area, Bureau of Land Mgmt., to Interested Parties (Nov. 9, 2011), available at http://www.blm.gov/or/districts/medford/plans/files/ Final_Scoping_Letter.pdf (describing proposed silviculture prescriptions for the Friese Camp Forest Management Project).

140. Silvicultural Systems and Harvest Methods Used in the Proposed Resource Management

Plan, BuREAU OF LAND
http://www.blm.gov/or/plans/files/CoosBayRMP/appendices/appendixe.html (last visited Apr. 17, 2014); see also OR. WILD, BLM PRACTICES VS. OREGON FOREST PRACTICES ACT (2012), available at http://www.andykerr.net/storage/conservation-uploads/forests/Oregon $\% 20 \mathrm{Wild} \%$ 20BLM\%20Practices\%20VS\%20OFPA.pdf.

141. OR. REV. STAT. $§ 527.740$ (2011); see also OR. Wild, OREGON WiLd COMPARISON TABLE (2012) (on file with author).

142. Jeff Mapes, Peter DeFazio Criticizes "Radical” Environmental Groups Fighting His Logging Bill, OREGONIAN (Oct. 3, 2013), http://www.oregonlive.com/mapes/index.ssf/2013/10/peter_defazio_ complains_about.html.

143. $\bar{I} d$.

144. Joseph Sax, Property Rights and the Economy of Nature: Understanding Lucas v. South Carolina Coastal Council, 45 STAN. L. REV. 1433, 1442 (1993).

145. Id. 
downstream flooding problems, the response has typically been to conjure a technological replacement such as a dam. ${ }^{146}$

Sax argues that protection of riparian zones from timber harvesting to prevent siltation could be seen as protection of a natural "transboundary service." 147 He suggests that our notion of property rights should adjust to new understanding of ecosystem services. In an "economy of nature" the landowner's role is unavoidably custodial - she does not have exclusive dominion of her land, but instead has only a right to uses compatible with the community's dependence on the property as a resource. ${ }^{148}$

While such an approach would undoubtedly improve outcomes where logging roads are adversely affecting river ecosystems, it is not necessary to fundamentally alter property rights to create a more efficient system of logging road regulation. Below I suggest federal permitting through NPDES, which has the ability to reform the relationship between logging roads and adjacent rivers and streams.

\section{FEDERAL PERMITTING}

\section{A. Federal Permitting Comports with the CWA and the 1987 Amendments}

Requiring stormwater permits through the NPDES system is not only good policy: it is also consistent with the CWA and the 1987 stormwater amendments. Recall that the Court's judgment in Decker rested on a view that the 1987 amendments "exempt from the NPDES permitting scheme most discharges composed entirely of stormwater. The general exemption, however, does not extend to all stormwater discharges."149 It is true that CWA section 402(p) begins with an exemption and then lists five categories where it does not apply. However, the purpose of the 1987 amendments was not to exempt stormwater from permitting - it was to force EPA to permit the most problematic types of stormwater pollution. Framing the amendments as broad exemptions of most types of stormwater belies Congress's purpose.

Section 402(p) of the 1987 amendments does not, as Justice Kennedy put it, "exempt" discharges composed entirely of stormwater. ${ }^{150}$ What it actually says is that "[p]rior to October 1, 1994, the Administrator or the State . . shall not require a permit under this section for discharges composed entirely of stormwater."151 As originally adopted, section 402(p)(1) specified that the moratorium on permitting stormwater discharges other than the five categories specified in the statute would expire on October 1, 1992. Congress later extended the deadline to October $1,1994 .{ }^{152}$ The legislative history of this

146. Id.

147. Id. at 1444 .

148. Id. at 1452 .

149. Decker v. Nw. Envtl. Def. Ctr., 133 S. Ct. at 1332 (internal citations omitted).

150. Id.

151. CWA $\S 402(p)(1), 33$ U.S.C. $§ 1342(p)(1)$ (2012) (emphasis added).

152. Pub. L. 102-580, § 364, 106 Stat. 4862 (Oct. 31, 1992). 
amendment is scarce - it refers only to a "technical amendment" to the CWA that was passed by a voice vote in the House and shortly thereafter in the Senate. ${ }^{153}$ This change shows that Congress decided to allow EPA to require a permit for discharges composed entirely of stormwater. Insofar as a temporary moratorium existed for permitting other types of stormwater pollution, it ended in 1994. Given that the 1994 deadline is the most current version of the law, it is certainly true that in the twenty years since then, EPA could have required a permit for discharges composed of stormwater, regardless of whether it considered them to be from "industrial" sources. Thus, despite EPA's reluctance to permit stormwater discharges, Congress clearly expected EPA to do so in the future when it passed the 1987 amendments. Furthermore, since EPA may require a Phase I permit for any type of stormwater discharge, the regulatory solution I propose for forest stormwater is legally sound despite the Court's ruling, which held only that EPA cannot be forced to permit forest stormwater through Phase I. Note that EPA has also not permitted forest stormwater through the more discretionary Phase II process, which thus far covers only small MS4s and small construction sites. ${ }^{154}$

Although EPA revised its Industrial Stormwater Rule during the Decker litigation to unambiguously prevent inclusion of logging roads as "industrial sources," it would have at least two options if it chooses to permit logging roads as I suggest. One would be simply to repeal the most recent regulation or revise it to include, rather than exclude, logging roads. Another would be to use the final provision of the 1987 stormwater amendments: "A discharge for which the Administrator or the State, as the case may be, determines that the stormwater discharge contributes to a violation of a water quality standard or is a significant contributor of pollutants to waters of the United States." 155 Because EPA lists two-thirds of Oregon's assessed waterways as impaired, ${ }^{156}$ this may provide the necessary authority to implement federal stormwater permitting, should EPA choose to do so.

\section{B. Success With General Permitting for Other Systems}

EPA has used general permits to satisfy the requirements of the CWA since 1979. ${ }^{157}$ General permits may contain enforceable effluent limitations and other requirements, but unlike individual permits, they apply to large numbers of sources discharging into multiple bodies of water. ${ }^{158}$ If a discharger believes itself to be covered by a general permit, it may submit a "notice of

153. Id.; see also Hill \& Allnutt, supra note 28, at 164.

154. EPA, supra note 35.

155. CWA $\S 402(\mathrm{p})(2)(\mathrm{E})$.

156. Oregon Water Quality Assessment Report, EPA, http://ofmpub.epa.gov/waters10/attains state.control?p_state=OR (last updated Apr. 18, 2014).

157. Jeffrey M. Gaba, Generally Illegal: NPDES General Permits under the Clean Water Act, 31 HARV. ENVTL. L. REV. 409, 410 (2007).

158. Id. at 411 . 
intent" (NOI) to discharge in compliance with the general permit. ${ }^{159}$ The CWA contains no specific provisions applicable to issuance or content of general permits; they are subject to the same provisions applicable to all NPDES permits. $^{160}$

Because of the lack of pollution control technology for many of the discharge types that general permits cover, such as concentrated animal feeding operations, concrete plants, and sewer systems, EPA regulations allow permits to employ BMPs to minimize discharge of pollutants. ${ }^{161}$ However, Professor Jeffrey Gaba argues that many broadly applicable, BMP-based permits are fundamentally inadequate to meet water quality standards (WQS), which are

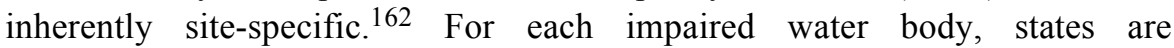
theoretically supposed to determine the total amount of a specific pollutant that can be discharged without violating the WQS - this amount is called a Total Maximum Daily Load (TMDL). ${ }^{163}$ TMDLs have not been designated for the vast majority of water bodies, and Gaba argues that general permits actually discourage development of TMDLs by exempting permittees from any WQSbased requirements on streams without approved TMDLs. ${ }^{164}$ Although this is a serious problem for general permitting, and impacts the permitting process I propose, it is beyond the scope of my analysis here. Despite these challenges, general permitting of forest stormwater is the best way to achieve cost-effective improvements in water quality.

General permits have been used in a variety of contexts. In addition to "industrial" sources, the 1987 amendments also require NPDES permitting for "large" MS4s, which serve cities of more than 100,000 people. ${ }^{165}$ Roads within the boundaries of large, medium, and small MS4s are already part of NPDES and are subject to BMPs as outlined in their permits. ${ }^{166}$ When entire classes of dischargers create similar types of water pollution, agencies have used NPDES general permits to reduce the administrative burden by authorizing discharges from a category of point sources within a specified area. ${ }^{167}$ The process also

159. 40 C.F.R. $\S 122.28(b)(2)(2013)$.

160. See Gaba, supra note 157 , at 411.

161. Id. at 417. Although the CWA only authorizes the use of BMPs as technology-based limits for control of toxic pollutants, EPA regulations authorize BMPs where necessary "to carry out the purposes and intent of the CWA." 40 C.F.R. $\S 122.44(\mathrm{k})(4)$.

162. Gaba, supra note 157 , at 439.

163. CWA $\S 303(d)(1)(C), 33$ U.S.C. $\S 1313(d)(1)(C)(2012)$.

164. Gaba, supra note 157 , at 439 .

165. CWA $\S 402(\mathrm{p})(2)(\mathrm{C})-(\mathrm{D})$. Approximately $1000 \mathrm{MS} 4 \mathrm{~s}$ are permitted under NPDES Phase I. See also LAura Gentile et AL., StORM WATER Phase I MS4 Permitting: Writing More EFFECTIVE, MEASURABLE PERMITS (2003), available at http://water.epa.gov/polwaste/nps/stormwater/upload/ 2003_03_26_NPS_natlstormwater03_13Gentile.pdf. For Phase II discharges, Congress instructed EPA to issue regulations based on studies it performs. CWA $\S 402(p)(5)-(6)$. In 1999, EPA promulgated a Phase II regulation requiring NPDES permits for discharges from small municipal storm systems and small construction sites. The Ninth Circuit upheld most of the regulation in Environmental Defense Center v. EPA, 344 F.3d 832 (9th Cir. 2003), and remanded for further proceedings.

166. 40 C.F.R. $\S 122.26(\mathrm{a})(1)(\mathrm{v})$.

167. Id. $\S 124.19(\mathrm{a})$. 
simplifies the requirements of regulated dischargers. Most municipal dischargers take advantage of the NOI submission process rather than applying for an individual permit.

General permits allow administering agencies to structure effluent standards, monitoring and reporting, and maintenance in order fulfill the CWA's requirements. ${ }^{168}$ General permitting has fostered better management techniques, including creation of Stormwater Pollution Prevention Plans (SWPPPs) - these in turn allow for implementation of "appropriate control measures" and other strategies to minimize pollution in discharges. ${ }^{169}$ One scholar has observed that these management-based strategies tend to give operators responsibility for developing their own responses to environmental problems, thereby leveraging their superior knowledge about the risks and benefits of particular methods." 170

Because MS4 permits are BMP-based, determining compliance is more difficult than with traditional NPDES permits, which use a relatively simple process of comparing wastewater sampling results with permitted discharge limits. ${ }^{171}$ To aid permit writers, EPA has given examples of both enforceable and unenforceable language. ${ }^{172}$ Compliance is easier to achieve when permits contain quantifiable, measurable elements, as is currently required for Phase II MS4 systems, but not for the larger Phase I systems. ${ }^{173}$ Despite these difficulties, NPDES regulation of MS4 stormwater pollution has been broadly successful, particularly in the case of point source pollution such as industrial pollution and municipal waste that is discharged into MS4s. ${ }^{174}$

EPA has also demonstrated the effectiveness of an NPDES general permit for pesticide application. Following a Sixth Circuit decision in National Cotton Council v. EPA, point source discharges of biological pesticides are required to comply with NPDES permits. ${ }^{175}$ As a result, EPA issued its Pesticide General Permit (PGP) for pesticide operators. Most states have now taken on the role of CWA permitting authority-section 402(b) authorizes this transfer if a state's

168. See id. $\S \S 122.41(\mathrm{a})(1), 122.41(\mathrm{~d}), 122.31(\mathrm{e})$.

169. EPA, Multi-Sector General Permit For StOrmwater Discharges AsSOciated With INDUSTRIAL ACTIVITY pt. 5 (2009), available at http:// www.epa.gov/npdes/pubs/msgp2008 finalpermit.pdf.

170. Cary Coglianese, The Managerial Turn in Environmental Policy, 17 N.Y.U. ENVTL. L.J. 54, 55 (2008).

171. GENTILE ET AL., supra note 165. Although I argue that state-level BMPs are currently inadequate to address Oregon's forest stormwater problems, BMPs are ultimately essential to any general permitting scheme. Thus BMPs are not per se unworkable from a policy-making perspective.

172. Id. Unenforceable permit language includes provisions such as "timely implementation," listing BMPs but not specifying where, how much, or how often the BMPs must be employed, and "to the maximum extent practicable." Enforceable provisions are more specific, describing, for example, a timeline for inspections, a deadline for achieving an action, or a frequency for continuing performance. Id.

173. Id. at 140 .

174. John H. Minan, Municipal Separate Storm Sewer System (MS4) Regulation under the Federal Clean Water Act: The Role of Water Quality Standards?, 42 SAN DIEGO L. REV. 1215, 1227 (2005); see also id. at 1256 (describing NPDES as a "success").

175. See Nat'l Cotton Council of Am. v. EPA, 553 F.3d 927, 940 (6th Cir. 2009). 
laws and regulations establish a permit program that is substantially equivalent to the federal program. ${ }^{176}$ The vast majority of states now have full or partial NPDES permitting authority. ${ }^{177}$ Although EPA is now the permitting authority in only four states, it is possible for state environmental agencies to use EPA's PGP for their own pesticide permitting. ${ }^{178}$ The PGP is 174 pages and contains provisions for how to obtain authorization by submitting an NOI, how to comply with technology-based limits and water quality standard-based limits, and monitoring provisions. ${ }^{179}$

When a discharger submits an NOI, it must include a pesticide discharge management plan, which documents how decision makers will implement the effluent limitations. ${ }^{180}$ The permit also contains provisions for problem identification, evaluation of options, response procedures for spills and other emergencies, and a list of "corrective actions" for situations requiring revision of the operator's pest management measures, such as failure to meet applicable water quality standards. ${ }^{181}$ The permit also provides provisions applicable to specific states and territories, which reflect site-specific conditions. ${ }^{182}$

Successful control of multiple pollution sources through the general permitting process demonstrates that applying the NPDES program to logging roads is both feasible and not overly burdensome. ${ }^{183}$ I next present a proposal for how forest stormwater permitting would work, based on successful permitting in other contexts.

\section{The Forest Road Stormwater Permitting Process}

Permitting logging roads through NPDES is likely simpler than permitting non-logging roads as part of MS4 systems because discharges from highways and municipal roads are generally larger and have more varied pollutants than logging roads. ${ }^{184}$ It should also be simpler than already-permitted "industrial"

176. CWA $\S 402(b), 33$ U.S.C. $\S 1342$ (b) (2012); see also 40 C.F.R. $\S 123$ (2013) (state program requirements).

177. See State Program Status, EPA, http://cfpub.epa.gov/npdes/statestats.cfm (last updated Apr. 14, 2003).

178. As of February 2012, the four states in which NPDES is the permitting authority are Idaho, Massachusetts, New Hampshire, and New Mexico. Also included are Washington D.C. and all U.S. territories. See Pesticide Applications Page, EPA, http://cfpub.epa.gov/npdes/home.cfm?program_id=410 (last visited Apr. 17, 2014).

179. EPA, PestiCide General PERMit 2-1 to 4-1 (2011), available at http://www.epa.gov/npdes/ pubs/final_pgp.pdf.

180. Id.

181. Id.

182. Id. at 9-2 to 9-64. These provisions only cover the states and territories for which EPA is the permitting authority.

183. See Brief for Former State and Federal EPA Officials Supporting Respondent at 11, Decker v. Nw. Envtl. Def. Ctr., 133 S. Ct. 1326 (2013) (No. 11-338), 2012 WL 5353858, at*11.

184. See Brief for Environmental Protection Information Center Supporting Respondent at 20-21, Decker v. Nw. Envtl. Def. Ctr., 133 S. Ct. 1326 (No. 11-338), 2012 WL 5363886, at *20-21; MiCHAEL E. BARBer et Al., Preliminary EnVironmental InVESTigation of HeAvy Metals in Highway RUNOFF 1 (2006), available at http://www.wsdot.wa.gov/NR/rdonlyres/A3518878-820F-4EBD-9D47C518AA2F8C91/0/PrelimEnvironmentalInvestigationHeavyMetals.pdf ("Federal Highway 
facilities, including construction sites, landfills, and open dumps, which each encompass different pollutants, operations, and discharge types. ${ }^{185}$

Despite these comparisons, it is unavoidable that my proposal will add new requirements to federal and state agencies that are already overburdened and underfunded. With this in mind, I have sought to outline a process that economizes on information at each relevant tier of decision making, accounting for local conditions while avoiding redundancy. I suggest that EPA first pass a regulation requiring a permit for discharges composed of forest stormwater. This is consistent with CWA section 402(p), which prohibits EPA from doing so only prior to 1994 , and thus allows permitting at any time after 1994 . To minimize the regulatory burden, I suggest that the regulation apply only to logging roads that are within 300 feet of a river or stream for a substantial portion of their length, and which discharge directly into the water body through pipes, channels, or other defined and discrete conveyances. ${ }^{186}$ This would address the substantial riparian stormwater pollution problems in coastal Oregon and similar areas, but would not require every forest road in the country to be subject to the same standards where not warranted. It would also restrict NPDES permitting to "point sources" within the meaning of the CWA.

One amicus writing on behalf of NEDC argued that dischargers could satisfy their permitting obligations by enrolling in existing stormwater general permits. EPA and the states have issued nationwide and statewide general permits for industrial discharges to comply with Phase I of CWA section 402(p). ${ }^{187}$ EPA theoretically could require logging road operators to comply with these old permits to satisfy any new permit obligation. EPA's 2009 MultiSector General Permit for Stormwater Discharges Associated with Industrial Activity (MSGP) was flagged as a candidate. ${ }^{188}$ Most state-level industrial stormwater permits are largely modeled on the MSGP. The MSGP requires permitted dischargers to prepare SWPPPs for permit coverage-these in turn allow for implementation of "appropriate control measures" and other strategies to minimize pollution in discharges. ${ }^{189}$

Because of the myriad differences between industrial pollution and forest road pollution, I suggest that EPA write a new general permit specifically for forest stormwater, utilizing the SWPPP process. I suggest that EPA draft a "Forest Stormwater General Permit" (FSGP), which would apply to roads used for timber harvesting in the four states for which EPA is the permitting

Administration (FHWA) identifies cadmium, chromium, copper, iron, lead, nickel, and zinc as the metals typically associated with highway runoff.").

185. See EPA, supra note 169 , at 47-138.

186. The Trask River Road, one of the roads that led to the Decker case, is within fifty feet of the Trask River in Tillamook State Forest, Oregon. See Trask River Rd, Tillamook, OR, GoogLE MAPS, http://goo.gl/maps/ev1he. In this area, general permitting would cover most if not all of the logging roads.

187. Authorization Status for EPA's Stormwater Construction and Industrial Programs, EPA, http://cfpub.epa.gov/npdes/stormwater/authorizationstatus.cfm (last visited October 1, 2013).

188. EPA, supra note $169, \S 8$. A.6, app. D-2.

189. Id. 
authority, and which would be available to the remaining forty-six states to use for their own state-level NPDES permitting. In Decker, the brief for state amici opposing NPDES permitting noted that in the forty-six states ${ }^{190}$ that are authorized to implement NPDES, the ultimate burden of implementing general permits would rest with the states. ${ }^{191}$ It is therefore necessary to ease this burden on individual states by providing them with a template, similar to the MSGP described above. The states would be allowed to draft their own forest general permits, but they would probably choose to utilize EPA's template to save resources. Forest conditions and logging practices differ between and even within states that practice logging, so the template should contain enough blanks for the state-level permit writers to customize the permit to fit their needs. However, since the general permit would only cover logging roads that have a connection to rivers and streams, the roads it covers probably will have more similarities than differences.

The MSGP and its state-level analogs, along with EPA's recently drafted PGP, provide lessons in permit drafting. I suggest separate permit sections describing coverage, BMPs derived from the best available state-level forest road rules, monitoring provisions, and a plan for record keeping and corrective action. Individual dischargers, in order to submit an NOI, should prepare an SWPPP, which is intended to document the selection, design, and installation of pollution control measures. The SWPPP also includes a site description and summary of potential pollution sources. To the extent that protective state-level BMPs get codified in a state's general permit, and a discharger is already complying with them, the discharger would merely have to codify them in its SWPPP. On the other hand, if a state's permit imposes tougher limitations than before, a discharger's SWPPP will have to detail how it will achieve compliance.

Logging roads have many common elements, including pollutants of concern, road layout, stream crossings, and maintenance. ${ }^{192}$ Because of these, EPA should write into its template FSGP a set of "core" BMPs that all states should follow. If a state permitting authority decides not to follow these, it should have to justify its choices to EPA before EPA approves its permit. EPA should also leave blanks in its template FSGP that allow state permitting authorities to account for local conditions, like average rainfall, which inevitably will complicate nationwide regulation. As I discuss below, the goal of permitting should be to approach and eventually achieve WQS in water bodies that receive forest stormwater pollution.

Finally, the CWA allows variances for economic hardship. Permitting authorities need not require point source dischargers to satisfy effluent levels if

190. See Memorandum of Agreements, EPA, http:/www.epa.gov/compliance/resources/policies/ state/moa/ (last updated Sept. 4, 2013). The four states that are not the NPDES permitting authority are Idaho, Massachusetts, New Hampshire, and New Mexico. Id.

191. See Brief for Arkansas Supporting Petitioner, supra note 53, at 24.

192. See Brief for Former State and Federal EPA Officials Supporting Respondent, supra note 183 , at 19 . 
those dischargers show that they will apply "the maximum use of technology" that is economically feasible, and that their actions will create "reasonable further progress" toward pollution reduction. ${ }^{193}$ Therefore, while a permit is necessary for point source discharges into navigable waters, permitting authorities have "necessary flexibility in the shaping of permits that is not inconsistent with the clear terms of the Act."194

\section{Advantages of General Permitting Applied to Logging}

\section{Runoff Reduction}

The FSGP is not permitting for permitting's sake; it would be specifically designed to reduce pollution going into waterways. It would allow the federal government to overcome the shortcomings of state-level pollution control while also taking advantage of state-level BMPs that are already effective. A permitting system based in large measure on BMPs raises the question of how it would improve upon the existing BMP-based approach. ${ }^{195}$ First, federal permitting would raise all dischargers to BMP standards that are effective. As I have argued, some states' BMPs are more protective than others, and federal permitting can prevent state-level collective action problems from creating BMPs that are not protective enough of waterways. Permitting would also help force compliance with existing BMPs, which is far from guaranteed at present. It would do this through water quality-based contingencies and greater availability of enforcement actions, both of which I discuss below.

Second, NPDES permitting would complement BMP programs already in place by encouraging logging road operators to limit the number of point sources discharging sediment from their roads. Logging road operators could keep the vast majority of logging road discharges out of the NPDES permit's provisions by ensuring that as much as possible is discharged into adjacent hillsides and lands that do not enter any water body. ${ }^{196}$ The FSGP would encourage logging operators to vigorously implement runoff-reducing BMPs, such as properly spaced cross-drains, culverts, rolling dips, wing ditches, and water bars that channel stormwater onto an adjacent slope so that it seeps into the soil rather than discharging directly into waterways. ${ }^{197}$ Consequently, the

193. CWA $\S 301(c), 33$ U.S.C. $§ 1311$ (c) (2012); see also Natural Res. Def. Council v. Costle, 568 F.2d 1369, 1379 (D.C. Cir. 1977).

194. Costle, 568 F.2d at 1382.

195. See Brief for Arkansas Supporting Petitioner, supra note 53, at 23-25.

196. See Brief for Environmental Protection Information Center Supporting Respondent, supra note 184 , at 17 .

197. See Tex. Forest Serv. \& Tex. Forestry Ass'N, Texas Forestry Best Management PRACTICES 30-47 (2010), available at http://texasforestservice.tamu.edu/uploadedFiles/Sustainable/ bmp/Publications/BMP\%20Manual_Aug2010\%20-\%20web.pdf. NEDC noted that in the areas at issue in Decker, only about 25 percent of the stormwater from logging roads is collected and discharged by man-made conveyances into navigable waters. In addition, only a fraction of those roads contains active timber cutting and hauling at any given time. Brief for Respondent at 54, Decker v. Nw. Envtl. Def. Ctr., 133 S. Ct. 1326 (2013) (No. 11-338), 2012 WL 4910210, at*54. 
scheme would focus permit provisions on actual discharge locations, such as stream crossings where a logging road passes over a waterway, or outfalls where logging roads are adjacent to stream channels. This would improve on the shortcomings of existing BMP-based systems by factoring in better information about the actual discharge locations and providing for more robust monitoring. ${ }^{198}$

\section{Compliance with Water Quality Standards}

General permitting requires dischargers to comply with WQS under the CWA. The CWA's WQS provision requires states to identify waters that are polluted after the application of technology standards, prioritize these waters, and establish TMDLs for them at levels necessary to meet applicable WQS. ${ }^{199}$ Oregon's 2006 list of impaired waters shows nearly 12,000 stream miles in violation of WQS for sediment, and 31,000 miles impaired overall. ${ }^{200}$ Nationally, sediment pollution impairs hundreds of thousands of miles of rivers and streams. ${ }^{201}$ However, Oregon has prepared TMDLs for fewer than 6000 miles of rivers, and sediment remains a major pollution problem. ${ }^{202}$ Although Professor Gaba notes that general permitting raises serious questions about compliance with WQS, and may actually discourage creation of TMDLs, the FSGP would be an improvement over the current situation of open noncompliance with WQS. ${ }^{203}$

First, general permitting would allow the permitting authority to exclude from coverage any road discharging into already impaired waters. ${ }^{204}$ This would allow gradual decommissioning of roads causing the most water quality problems, and strategic location of new roads in areas where they do not cause water quality programs.

Second, it is possible to include in the general permit a requirement that any covered discharge not violate WQS. Enforcement of this requirement would be more complicated than simply monitoring the quality of the discharge, as is done for individual permits; it would require assessment of instream water quality and then working backwards to prove that the discharger was responsible impaired conditions. This is arguably one of the problems Congress tried to avoid when it enacted NPDES in the first place. ${ }^{205}$ However,

198. See Brief for Environmental Protection Information Center Supporting Respondent, supra note 184 , at 19 .

199. CWA $\S 303(d)(1)(A)-(C), 33$ U.S.C. $§ 1313(d)(1)(A)-(C)(2012)$.

200. Site-specific Targeted Monitoring Results: Causes of Impairment, Oregon Rivers and Streams (2006), EPA, http://ofmpub.epa.gov/waters10/attains_state.control?p_state=OR (last visited Apr. 17, 2014).

201. National Summary of Impaired Waters and TMDL Information, supra note 50.

202. See Site-specific Targeted Monitoring Results: Causes of Impairment, Oregon Rivers and Streams (2006), supra note 200.

203. See Gaba, supra note 157 , at 436 .

204. Id.

205. See id. at 441 . 
despite these difficulties, at least one court has upheld the enforceability of a generic WQS compliance provision. ${ }^{206}$

Since the waters into which logging roads are discharging are often in violation of WQS, such a general prohibition may not achieve much more than theoretical violations that lack corresponding improvements. For this reason, EPA's MSGP requires that if a discharge contributes to violation of WQS, the discharger must take "corrective actions" and undertake monitoring. ${ }^{207}$ EPA can also withdraw coverage under the MSGP or require the discharger to obtain an individual permit. EPA has also made the case that since permits generally have an expiration date, subsequently issued permits can be "better-tailored" to meet WQS - thus, over time, permitting conditions can improve to fit the needs of impaired waterways. ${ }^{208}$ My conclusion is that while there are still problems in applying the general permit framework to WQS, the existing noncompliance with WQS means that even if general permits' measures are not perfect, they would be a huge improvement over a complete lack of permitting.

\section{Availability of Citizen Suits}

Another significant advantage of applying NPDES to logging roads is the contribution of citizen suits to enforcement. The CWA's citizen suit provision authorizes private citizens to bring enforcement actions against persons violating an "effluent standard or limitation," which is defined to include discharge without a permit or violation of a "permit or condition." 209 NPDES permitting would therefore give citizens the incentive to monitor waterways and ensure that the discharger complies with its applicable permit, which, as mentioned above, would include provisions governing continued violation of WQS. In Tillamook State Forest, NEDC documented numerous discharges and Total Suspended Solids approaching 2000 times background levels from six discharge points on Trask River Road and five discharge points on Sam Downs Road, yet its lawsuit became an examination of whether EPA is required to regulate forest stormwater discharges as point sources. ${ }^{210}$ If in the alternative, EPA required general permits, a citizen suit would be more properly focused on whether there was a violation of an existing permit. This provision would encourage dischargers to comply with their permits and would stimulate citizen involvement in protecting water quality.

206. See Nw. Envtl. Advocates v. City of Portland, 56 F.3d 979, 990 (9th Cir. 1995).

207. EPA, Multi-Sector General Permits For Stormwater Activities Associated With INDUSTRIAL ACTIVITY (2006), available at http://www.epa.gov/npdes/pubs/msgp2006_all-proposed.pdf.

208. Letter from Robert Perciasepe, Assistant Adm'r, EPA, to State Water Program Directors (undated), available at http://www.epa.gov/npdes/pubs/swpol.pdf.

209. CWA $\S \S 505(a)(2), 505(f), 33$ U.S.C. $\S \S 1365(a)(2), 1365(f)(2012)$.

210. Recent Cases, WASH. FOREST L. CENTER, http://wflc.org/cases/docket/nedcvbrown (last visited Apr. 14, 2014). 


\section{E. $\quad$ Potential Problems With General Permitting Applied to Logging}

It is true that where states, not EPA, are the NPDES permitting authority, NPDES permitting may not be a panacea for overcoming state-level collective action problems. However, it is likely that state-level NPDES permitters have a stronger incentive to develop protective standards than state forestry departments, which typically oversee BMPs. For instance, in Oregon the Oregon Department of Environmental Quality is responsible for NPDES permitting, whereas BMPs are determined by the Oregon Department of Forestry. The diversification of regulatory views alone could facilitate more protective forest stormwater rules. Furthermore, the Department of Environmental Quality's institutional mission includes protecting water quality, whereas the Department of Forestry's does not, and Department of Environmental Quality has existing authority and experience with NPDES permitting. ${ }^{211}$ These factors should facilitate creation of permits that actually work. $^{212}$ Furthermore, although EPA rarely does so, it has the power to veto state-issued permits as insufficient. ${ }^{213}$ It is also significant that EPA continues to be the permitting authority on federally owned land even where the state is the main authority, and in four states including Idaho, which faces significant threats to its aquatic ecosystem from logging. Thus, while NPDES permitting may not be a panacea, it can be a first step toward finally confronting the problem of forest stormwater pollution.

\section{CONCLUSION}

Congress passed the Clean Water Act with the express goal to "restore and maintain the chemical, physical, and biological integrity of the nation's waters." Although point source permitting of industrial sources has been highly effective, the nation's waters remain impaired due to sediment pollution-a problem that seems less perilous to water quality than outfalls from industrial facilities, but which defies the technology-based limits that NPDES permitting has successfully used. In Decker, plaintiff NEDC sought to hold the state of Oregon liable for unpermitted stormwater discharges from logging roads, under CWA section 402's permitting requirement for "industrial" sources. The Supreme Court held that Oregon was not required to issue a permit for these discharges, because EPA was entitled to deference in its view that the logging roads at issue were not "industrial" in nature.

I have argued that maintaining the status quo is undesirable because pollution from logging roads is not just a theoretical problem-it has highly

211. See About Us, OR. DeP'T ENVTL. QuALITY, http://www.oregon.gov/deq/Pages/about_us.aspx (last visited Apr. 17, 2014) ("DEQ is responsible for protecting and enhancing Oregon's water and air quality ....").

212. See ADLER, supra note 10, at 186-87 (1993) (noting that one of the reasons CWA section 208 failed was because it was executed by agencies that lacked a water quality focus). Bringing in an agency that does focus on water quality would be beneficial for this reason.

213. CWA $\S 402(d)(2)$. 
detrimental effects on the entire downstream ecosystem, particularly salmon. The existing solution to this problem suffers from several shortcomings that limit its effectiveness and allow continued sediment discharge. I believe that NPDES permitting is a solution to this problem, and is an option available to EPA even following Decker. Although NPDES forest stormwater permitting is untested, and all issues have not yet been resolved, it is clear that existing regulations on this issue are failing to realize the original goals of the CWA. In turn, they are failing the aquatic ecosystems that rely on clean water and the people, from the fishermen to the general public, who benefit from healthy and productive ecosystems. ${ }^{214}$

Although this Note has assumed that EPA may at some point decide to implement NPDES permitting for logging stormwater, it is undeniable that such a position would require a surprising change of course. After all, Decker validated EPA's contrary view - that it need not regulate in this area. Although EPA relied on legal arguments, such as Auer deference to agency interpretation, rather than policy rationales, and thus may be open to the policy arguments in favor of permitting, it is also likely that it has its reasons for opposing permitting. EPA may not have an adequate budget to take on new responsibility. It may worry that Congress would cut its funding if it embarks on a new - and potentially unpopular - regulatory program. It may worry about the practical difficulties of permitting. These concerns are legitimate, but it is equally true that one of the CWA's strengths is its ambition. It was passed at a time when rivers were so polluted that some caught fire. Congress deliberately passed a "tough law," overriding President Nixon's cost-conscious veto. ${ }^{215}$ I believe that our regulators can rise to the challenge of confronting the main remaining obstacle to the CWA's original goals.

There may also be hope for future plaintiffs in the wake of Decker. NEDC sought to compel permitting for logging roads with CWA section 402(p)(2)(B), which requires a permit for discharges "associated with industrial activity." The Court held that logging roads are not associated with industrial activity, and therefore that this provision does not compel permitting. However, an additional Phase I provision may suit plaintiffs' goals. Section 402(p)(2)(E) requires a permit for "a discharge for which the Administrator or the State, as the case may be, determines that the stormwater discharge contributes to a violation of a water quality standard or is a significant contributor of pollutants to waters of the United States." 216 This portion of the statute thus does not implicate EPA's Industrial Stormwater Rule, which was at issue in Decker. Although many of the rivers near Tillamook State Forest are untested for

214. See, e.g., Federal Judge Restores Endangered Species Act Protections for Oregon Coast Coho Salmon, EARTHJUstice (Oct. 9, 2007), http://earthjustice.org/news/press/2007/federal-judgerestores-endangered-species-act-protections-for-oregon-coast-coho-salmon (reporting that Oregon's coho salmon were once a staple of its commercial fishery, although the fishery is now closed due to low population counts).

215. Natural Res. Def. Council v. Costle, 568 F.2d 1369, 1275 (D.C. Cir. 1977).

216. CWA $\S 402(\mathrm{p})(2)(\mathrm{E})$ (emphasis added). 
sediment loads, ${ }^{217}$ it is likely that many are impaired for sediment. If a plaintiff decides to take up this cause again, I recommend using section 402(p)(2)(E) as a basis for requiring stormwater permitting.

217. 2006 Waterbody Report for South Fork Trask River, EPA, http://ofmpub.epa.gov/waters10/ attains_waterbody.control?p_au_id=OR_1236120454399_0_8.8\&p_cycle=2006 (last updated Apr. 18, 2014) (assessing only "anadromous fish passage" and "water contact recreation," not sedimentation).

We welcome responses to this Note. If you are interested in submitting a response for our online companion journal, Ecology Law Currents, please contact ecologylawcurrents@boalt.org.

Responses to articles may be viewed at our website, http://www.boalt.org/elq. 